A global economy requires business organizations to cultivate their international holdings by respecting the national differences of their host countries and coordinating efforts for rapid innovation. In this essay we first review relevant literature in the areas of communication and innovation and explore how efforts toward innovative practices are directly related to globalism and business strategy. We then focus on issues associated with national culture, corporate culture, and professional culture that are relevant to strategies for researching business communication in global contexts. Finally, we suggest directions for future work.

Keywords: Implementation Strategies, Innovation, Organizational Communication, Professional Culture, Psycholinguistic Research. Technology-Intensive

Companies

\title{
Innovation, Corporate Strategy, and Cul- tural Context: What is the Mission for International Business Communication?
}

Jan Ulijn

Eindhoven University of Technology, The Netherlands

Dan O'Hair

University of Oklahoma, Norman

Mathieu Weggeman

Eindhoven University of Technology, The Netherlands

Gerald Ledlow

Central Michigan University, Mt. Pleasant

H. Thomas Hall

University of Oklahoma, Norman

Drior to the dawning of the new millennium, much was written about 1 innovation, culture, globalism, and strategy. Commentaries on organizational vision, effectiveness, direction, and mission usually noted the necessity to innovate and expand beyond normal limits and borders. Inherent within discussions of innovation and globalism are issues relating to national and organizational culture, and to a lesser extent the professional cultures of members of innovative, globalized business firms. What are the

Jan M. Ulijn holds a Jean Monnet Chair in Euromanagement at the Department of Organisation Science, Eindhoven University of Technology, The Netherlands, and has been a part-time visiting professor in the special MA program in Multilingual Business Communication at Ghent University (Belgium) and in the Production Management MS program at Darmstadt University of Technology (Germany). He received ABC's Outstanding Researcher Award in 1998 and was recently named a Fellow of the Society for Technical Communication.

Dan O'Hair is Professor and Chair of the Department of Communication at The University of Oklahoma. He has published over 40 research articles in com- 
forces precipitating such concerns? What role does intercultural communication play in formulating visionary and strategy revolutions?

In this essay, we begin by examining issues relating to the critical and dynamic nature of innovation, globalization, and strategy-concepts that have become increasingly ambiguous from their excessive use in trade and scholarly literature. We review some of the more prominent research. We then sample the literature on three concepts of culture that are critical to the task of researching global and innovative business communication: national culture, corporate culture, and professional culture. In our final section, we offer some directions where future business communication theory and research could profitably proceed.

\section{Emerging Realities for Business Communication}

We will argue, along with others, that many of the emerging realities for business (e.g., continual innovation, global markets, strategic planning, and technological change) have become so interrelated that in the fundamental process of developing a vision or mission, organizations often treat these realities as interrelated strategies rather than separate issues. It is no longer accurate or appropriate to strategize about innovation without an accompanying integrated discussion of global markets, foreign subsidiaries or alliances, and cultural issues related to international involvement.

Businesses in the 21st century face a wide array of complex opportunities including, but not limited to, expanding into global markets, devel-

munication, business, management, and psychology journals and volumes, and has authored and edited seven books on communication. He is the current editor of the Journal of Applied Communication Research.

Mathieu Weggeman is a professor of Organisational Science at Eindhoven University of Technology in The Netherlands with a primary expertise in innovation management. $\mathrm{He}$ is also an Associate Partner with Twijnstra Gudde Management Consultants where he advises international firms on strategy development, R\&D management, and the redesign of knowledge-intensive organizations. He has published several books and articles on strategy formulation and knowledge management.

Gerald Ledlow is the Executive Director of Corporate \& Organizational Services and Director of Healthcare Programs at Central Michigan University. He received his doctorate in Organizational Leadership from the University of Oklahoma in 1998. His research interests focus on managed care systems and communication and leadership.

Thomas Hall is a doctoral fellow in the Department of Communication at the University of Oklahoma. He received his master's degree in communication from the University of Arkansas-Little Rock in 1999. His research interests include organizational communication and intercultural communication.

Send correspondence to Jan Ulijn at Eindhoven University of Technology, P.O. Box 513, 5600 MB Eindhoven, The Netherlands or <j.m.ulijn@tm.tue.nl>. 
oping internal and external innovative products and practices to remain competitive, and attracting and retaining the most talented workforce possible. International markets have become enticing prospects in companies' efforts to increase market share and diversify offerings. Market potential becomes especially salient with international trade alliances emerging across the globe such as NAFTA, the European Union, ASEAN in Southeast Asia, and Mercosur in South America (Ohmae, 1998). Beyond market considerations, innovation efforts in the United States increasingly rely on foreign resources (Branscomb, Florida, Hart, Keller, \& Boville, 1999). Even research and development dollars that were previously spent almost entirely in the United States now find their way into foreign nations to the tune of $\$ 15$ billion a year, $10 \%$ of the total spent on R\&D (Branscomb, et al., 1999). As organizations research, innovate, and market goods and services in foreign nations, the level of competition from both domestic and international firms becomes more intense.

Maintaining a competitive edge in a global, innovative, and dynamically evolving environment produces substantial pressure to redefine how business is conducted. A hierarchical, bureaucratic structure is less responsive in such an environment, and a flatter, more responsive organizational pattern is required (Monge \& Fulk, 1999). As organizations reengineer their structures to become more proactive and accessible, new patterns of communication emerge. Organizations find it necessary to push decisionmaking authority to lower levels, employ cross-functional teams, and encourage organizational learning (Branscomb, et al., 1999). It is also essential for firms to increase and improve external communication with international suppliers, subsidiaries, alliance partners, and customers (Parker, 1996). The interrelationships of innovation, culture, globalization, strategy, and communication are unmistakable and become more visible with time. Each new start-up company, regardless of location, will view these forces as supportive components of a larger scheme.

Much of the research focusing on issues of innovation, globalization, strategy, and communication historically has examined these factors in isolation, without the benefit of triangulating their processes and implications. Furthermore, a number of theoretical assumptions have been made in each area that may no longer hold as organizations change their communication patterns and practices in response to changing conditions and new opportunities. Communication scholars face multiple obligations, responsibilities, and opportunities as the focus shifts from paradigms privileging one-company, one-country studies to research approaches informed by multilevel theorizing (Lewis \& Grimes, 1999; Weick, 1999) and more gestalt and inclusive forms of problem conceptualization. The remainder of this essay identifies previous research in innovation, culture, and strategy and suggests new perspectives that better reflect the true nature of these interrelated phenomena. 


\section{Innovation and Communication}

Both theoretical and applied communication researchers have devoted serious and productive effort to the study of innovation. Organizations are quick to support such research efforts given the fundamental nature of innovation as an element of business survival. Innovation is not a luxury but a requirement:

Innovation enables organizations to improve the quality of their outputs, revitalize mature businesses, enter new markets, react to competitive encroachment, try out new technologies, leverage investment in technologies that are so expensive that no single product can recoup them, and develop alternative applications for existing product categories, to name a few outcomes. For organizations which must adapt to changing competition, markets, and technologies, product innovation is not a fad. It is a necessity. (Dougherty, 1996, p. 424)

The emphasis on business innovation is further substantiated by surveys of organizations. CEOs of 669 firms across 10 industries around the world consider technological innovation as being the most critical concern in their competitive advantage (Little, 1997). Hogg's 1993 survey of European managerial competencies in telecommunications companies in 6 European countries (Britain, Germany, The Netherlands, France, Italy, and Spain) found that innovation and strategic vision were vital to the effective performance or junior and middle mangers, second only to communication skills. Being an innovator and having vision are included among the top 10 characteristics of successful entrepreneurs in a similar survey by Ernest and Young with Roper Starch Worldwide (1997).

In 1986, Ulijn and Gobits analyzed the psycholinguistic aspects of the dissemination of scientific and technical innovation across the main linguistic borders of Europe and concluded that this communication process had a clear cultural embedding. This dissemination process involved the transfer of technology from the national laboratories involved in military research into civilian applications such as environmental protection and energy conservation. Research such as this represents an opportunity for technical communicators (Roberts, 1991) to act as bridge builders between different professional sectors.

Other research involving communication and innovation has concentrated on audience analysis. At the core of this research is an application of the reader-writer-text chain-usually at a more refined level than at the broader organizational level. This interactive reader-writer-readability model, including an analysis of the communication process within and between the writer and the reader, developed by Ulijn and Strother (1995), uses psycholinguistics to analyze how international business communicators can format an innovation message on lexical, syntactic, and discourse levels. A systematic evaluation of questionnaires, interviews, 
and usability testing among the readers of an innovation message creates a feedback loop that can be used to optimize the conceptual and linguistic qualities of the product by increasing its efficiency. Since the classic study by Kaplan (1966) on circular (East), linear (Anglo-Germanic), and digressive (Latin) paragraphing in English writing, numerous studies have confirmed culture-related differences in discourse formats between English and other languages and cultures. Recent studies compare the structure of French and Dutch versions of a business letter and a coffeemaker's user manual (Ulijn, 1995, 1996), and English and Dutch paragraphing in a technical environmental brochure (Ulijn \& Campbell, 1997). Readers of Spanish, French, U.S., or Dutch business letters or a French or Dutch user manual have recognized these differences in structure and sometimes prefer their own (Ulijn, 1995, 1996). The Ulijn and Strother readability system based on their interactive model, which elicits this kind of feedback, might work effectively in professional contexts as business professionals attempt to communicate to an international audience about innovation in an interactive way.

Another body of research involving communication and innovation has concentrated on understanding how organizational members communicate change strategies. Most prominent among this research is that of Everett Rogers (Rogers, 1983, 1996; Rogers \& Shoemaker, 1971). Although Rogers' vast research program did not always focus on business firms, his model of the diffusion of innovations and subsequent work has served as a touchstone for scholars investigating how innovative products, practices, and even internal dynamics such as organizational reengineering could be accepted more readily by important stakeholders. Highlights from that long-term research program include how communication networks are used to carry innovation messages and how the acceptance and adoption patterns of individuals can be tracked according to a normal curve distribution of the population. Rogers (1983) identifies five categories of adopters: (a) innovators (those making decisions or even precipitating innovation), (b) early adopters, (c) early majority, (d) late majority, and (e) laggards. Much of Rogers' work involved communication across organizations, not within an organization. Bach's 1989 study of communication and innovation within a single organization did not find Rogers' categories. Bach has suggested that Rogers' innovation adoption model is less suited for internal organizational communication and more appropriate for innovation adoption contexts among organizations.

Another relevant area of research is implementation strategies. How decisions such as innovation plans are carried out by those responsible for implementation has been examined from multiple perspectives (for a review consult Miller, Hickson, \& Wilson, 1996). Two research programs devoted to implementation are worth noting. First, at a strategic or organization-wide level, Bourgeois and Brodwin (1984) identified five strategies 
that organizations can use when attempting to implement decisions. The commander model is employed when the organization makes a centralized decision, such as adopting a new innovation, and instructs or orders the rank and file to implement it. The change model approaches implementation efforts by using organizational structure and system properties such as incentives and rewards as inducements for acquiescence. When implementation must be negotiated and sold at senior levels, a collaborative model is put into place. The cultural model is employed when the organization attempts to use the corporate or organizational culture as a means of implementation success. Finally, a crescive model attempts to cultivate and nurture implementation among organizational members.

At the individual or interpersonal level, Nutt $(1986,1987,1989)$ developed a typology of implementation tactics that managers use with their subordinates that range from coercive moves from upper management where employees are simply told to implement decisions, to persuasive tactics that attempt to sell employees on the decisions made at higher levels. Research suggests that persuasive and participatory strategies have a better success rate in getting decisions implemented at the appropriate levels of the organization.

Other research has focused on interpersonal and network approaches to the strategies used to implement organizational change-a form of innovation adoption (see Lewis \& Seibold, 1998, for a comprehensive review). Most studies conclude that information sharing is a powerful tool for desensitizing employees to change, and that information of any type can moderate the anxiety associated with uncertainty that comes with impending change in an organization (Miller \& Monge, 1985; Smeltzer, 1991). Lewis and Seibold (1998) conclude that communication is at the heart of change adoption and implementation and that organizations would do well to employ communication strategies that emphasize information sharing, feedback, employee participation and influence, and collaboration.

Attempts to situate the origin and exchange of innovation messages in organizations have led to the study of communication networks (e.g., Albrecht \& Hall, 1991a, 1991b; Albrecht \& Ropp, 1984; Monge \& Eisenberg, 1987). Albrecht and colleagues (Albrecht and Hall, 1991a; Albrecht \& Ropp, 1984) investigated the extent to which members of various organizations talk about innovation or express innovative ideas to one another. In a series of studies examining various organizations (oncology department of a medical center, public school systems, human service, and manufacturing) they discovered that innovation talk is quite limited and that employees are rather timid in their expressions of innovative ideas. Innovation talk is usually confined to networks of people who are deemed trusting and accepting. In another study of networks and innovation, Albrecht and Hall (1991b) attempted to isolate networks where innovation talk and the expression of new ideas were prevalent and rewarded. Such 
communication patterns were discovered in informal innovation networks composed of "elites" or groups of people who developed strong links to one another through their discussion and interaction about innovation. Elites were considered by other elites to be "idea persons" and competent communicators and were perceived by outsiders (nonelites) to be more influential and credible than nonelites. Through their collective talk about innovation, elite networks were viewed as wielding substantial power within the organization.

The preceding discussion suggests some needed areas of communication research to help organizations that make innovation an important part of their strategy. First, with an increasing emphasis on innovative goals, how will organizations enhance their innovative communication practices through vision and mission statements? Second, with additional stakeholders involved in innovation, how can audience analysis be improved to accommodate a more diverse group of stakeholders? Third, if innovation becomes the norm in an organization with an accompanying lower level of resistance, what type of strategies can be employed to question the utility and integrity of a large number of innovation strategies? Fourth, how will flatter organizational structures affect innovation strategies?

\section{The Cultural Context: National, Corporate, or Professional?}

O'Hair, Friedrich, Wiemann, and Wiemann (1997) have defined culture as

the shared beliefs, values, and practices of a group of people. A group's culture includes the language or languages used by group members as well as the norms and rules about how behavior can appropriately be displayed and how it should be understood. (p. 9)

A review of the available literature suggests that three different but overlapping contexts of culture have been studied. National culture studies are among the most intensely and widely examined and usually involve an investigation into or speculation about how a country's national culture influences the communication behavior of domestic and/or foreign members of multinational corporations. A second prominent area of study has focused on corporate culture, or how members perceive the culture of their organization. Studies of this nature are interested in how the organization regulates, controls, and influences the behavior of its members through its values, language (jargon), rituals, and customs. The third cultural dimension, and one less studied by business communication scholars, is professional culture. Issues associated with cultural studies of this type include the extent to which professionals (e.g., scientists, engineers, and managers) identify with their professional discipline rather than with their organization. 


\section{National Cultures}

Hofstede's work $(1980,1991)$ serves as the quintessential representation of how national cultures influence business communication. Hofstede (1991) defined culture as the "collective programming of the mind which distinguishes the members of one culture from another" (p. 260). Based on an extensive research program involving more than 100,000 employees of IBM in 64 countries, he classified national cultures along five dimensions: (a) power distance, (b) collectivism versus individualism, (c) femininity versus masculinity, (d) uncertainty avoidance, and (e) long-term versus short-term orientation (Hofstede, 1980, 1991). Hofstede's taxonomy allows us to understand the relative difference in values and structure of organizational members from different cultures (Morley, ShockleyZalabac, \& Cesaria, 1997), but less so of their communication patterns.

National culture studies have occupied a great deal of journal space in the last two decades. We intend not to review all of the cultural studies that are relevant to business communication but rather to sample that body of work. Several recent studies have focused on Thailand, which has attracted interest from multinational corporations because of its friendly foreign-investment policies. In a study interested in determining the effects of cultural values (high uncertainty, high power distance, low individualism, low masculinity) on the communication practices of Thai business professionals, Sriussadaporn-Charoenngam and Jablin (1999) found a coherence between culture and communication. Thai business professionals reflected their cultural values by communicating in reserved, respectful, deferential, and intimate ways. A study by Gundling (1999) determined that Thai business professionals were more favorable toward personal forms of communication and tended not to prefer technological substitutions such as videoconferencing.

The Korean culture has also attracted attention from business communication researchers. Writing styles of Korean and U.S. business managers were compared using letters of complaint (Park, Dillon, \& Mitchell, 1998). For the comparison, letters for both cultural groups were written in English, although English was the second language for the Korean group. Koreans were found to use a less direct organizational pattern in their letters and tended to delay placement of the main point. The U.S. group, in contrast, employed a direct organizational style and stated very early in the letter the main point of the complaint. In another study, Lee and Jablin (1992) conducted a multiple comparison study of organizational employees from Korea, the United States, and Japan. Contrary to prevailing opinion, their study determined that Korean and Japanese workers do not share wholesale commonalities of business attitudes and communication practices simply because they hail from a similar cultural heritage. In fact, the study discovered that U.S. and Korean workers were more similar than were Japanese and Korean workers. Although some 
research insists on emphasizing different communication behaviors for Japanese business professionals, Hilton (1992) discovered in a survey of Japanese educators and business representatives that the use of English as a business language was perceived to be critically important to professional success and that English training for corporate employees was part of the strategic plan for global competitiveness.

Cultural values were examined in combination with relational, political, and economic variables in a study of Chinese managers' influence tactics with subordinates (Krone, Chen, \& Xia, 1997). Perhaps the most striking finding from this research was that managers used influence tactics that reflected both political and cultural grounding. To a lesser degree, managerial roles also affected which kinds of influence tactics were used. These results suggest that simply knowing the national heritage of organizational members does not guarantee that communication behavior can be predicted from Hofstedian principles.

Emphasizing receiver perception of messages across national borders was the focus of a study conducted by Ulijn and St. Amant (2000). The study asked 60 students from 5 countries (China, The Netherlands, Germany, France, and Italy) to view a taped Chinese-Dutch negotiation. Results indicated that asking questions and dealing with time were perceived differently depending on the national culture of the respondents.

The final area of research we review in the context of national culture is that of intercultural communication competence. Cooley and Roach (1984) offered what has become a well-quoted advisory about intercultural competence:

Communication behaviors that are the reflection of an individual's competence are culturally specific and, hence, bound by the culture in which they are acted out. As a result, behaviors that are understood as a reflection of competence in one culture are not necessarily understood as competent in another. (p. 13)

Beamer (1992) postulated a layered or "stacked disk" conceptualization of intercultural competence that included five levels: "(a) acknowledging diversity, (b) organizing information according to stereotypes, (c) posing questions to challenge the stereotypes, (d) analyzing communication episodes, and (e) generating 'other culture' messages" (p. 291). Sriussadaporn-Charoenngam and Jablin (1999) verified their model of communication competence in Thai organizations. Their model proposed three general competence factors composed of several behaviors and skills. Strategic Communication Knowledge included behaviors such as conflict avoidance, showing respect, and using correct language. Tactical Communication Skills included such behaviors as giving instructions/orders, networking, and writing, listening, and persuading. Behavioral Traits/Cognitive Abilities included three components: empathy, cognition, and 
Table 1

How Intercultural Communication Competency Is Defined by Recent Scholars

Competency Features

Author

Recognize communication styles and problem-solving strategies for a culture, identify potential for misunderstandings, compare expectations of self and others.

Bolten, 1999

Be aware of how judgments of value and reality are made by self and others, become sensitive to different ways of speaking and listening, develop readiness for making encounters and dialogue.

Steier, 1999

Develop superior language skills; research skills; analytic, interpretive, and rhetorical skills; language-learning; and cross-cultural skills.

Weiss, 1999

Avoid idioms and jargon; avoid long, complex sentences; use active voice; avoid referring to readers by nationality.

Stress collaboration, use cross-functional teams, experiment with different forms of organizational structure and leadership.

Bernhardt, 1999

complexity. Sriussadaporn-Charoenngam and Jablin ultimately conclude that what is regarded as competence may largely depend on the unique characteristics of a national culture, and that certain types of organizations, within the same culture, may require different types of competency.

Numerous other communication scholars have proffered their own conceptualizations of intercultural competence. Table 1 summarizes their basic tenets.

This review of national culture studies points out the need for additional business communication research. In particular, if the Hofstedian approach to studying business communication is being called into question (Gessner, Arnold, \& Mobley, 1999) due to the overgeneralization of cultural effects on communication (Lovitt, 1999) or because distinct cultural values are converging with other cultural values (Lovitt, 1999; Parker, 1996), where can empirical research productively situate its analysis of cultural influence on business messages? If preference for message style and strategy cannot be completely predicted from previous work, what types of measures and concepts are needed to understand business communication in different cultures? We also need to understand how media and technology interact with cultural expectations in business contexts. That is, can national culture predict how business professionals use 
or respond to media and technology? Can definitions of communication competence be determined for a particular culture, and, if not, can general competency models serve useful purposes? Finally, how can new models of psycholinguistic analysis be used in contexts where cultural congruence is apparent?

\section{National and Corporate Cultures}

Since innovation strategy often involves management of change, mergers, strategic alliances, joint ventures, and acquisitions, unexpected culture differences might lead to serious failures as demonstrated by a statistical study of foreign entry (Barkema, Bell, \& Pennings, 1996) and a case study about the decline of the Dutch aerospace industry (Heerkens \& Ulijn, 1999). Culture was also identified as a factor influencing the behavior of European multinational corporations (Kumar, Ulijn, \& Weggeman, 1997). While national culture has received most of the attention of communication researchers, recent work suggests that corporate and organizational culture can affect the content and form of communication.

The broader cultural context of multinational strategy involves an interaction between national culture and corporate culture. On the basis of Hofstede's research (1980, 1991), Schneider and Barsoux (1997) propose a national culture embedding for a particular corporate culture when innovation is the message (see Figure 1). Both the Anglo-Nordic village market culture visible in most North American and Northwestern European firms from a family or tribe Asian culture share low to moderate on the uncertainty avoidance but have very different power distances. Some northern European organizations have the more Germanic culture of the well-oiled machine and high uncertainty avoidance but low power distance, while most southern cultures, including Latin America, have the traditional bureaucracy with a pyramid of people, high on both indices. How important are uncertainty avoidance and power distance to the innovative capacity of a firm?

Weggeman (1989) and Nonaka and Takeuchi (1995) suggest that Japan pursues a different innovation strategy than the West by learning implicitly through oral communication, rather than the more Western explicit learning style by written instructions. In an ultimate effort to bring Northern, Southern, Western, and Eastern leadership roles in innovation together, Kalthof, Nonaka, and Nueño (1997) consider the examples of Michelin, Kao, and Sharp to outline the Platonic innovation spheres of the West (with North and South in a nice cooperation) and the Eastern intuition and vision, all of which leads to creation, elaboration, and orientation towards the market. What happens to the corporate culture of a given multinational firm with a rather homogeneous corporate culture when it settles in the United States, Northwestern Europe, Latin Europe or America, or Japan? 
Figure 1

Interaction of Uncertainty Avoidance and Power Distance in National and Corporate Cultures

\begin{tabular}{lll}
\hline$\uparrow$ & Village market & Family or tribe \\
Low & (Anglo/Nordic) & (Asian) \\
& Decentralised & Centralised \\
& Generalist & Paternalistic \\
& People as free agents & Loyalty \\
& Entrepreneurial & Generalist \\
& Flexibility & Strong social versus task roles \\
& More delegation & Personal relationships \\
& Output control & Social control \\
Uncertainty & & \\
Avoidance & & Traditional bureaucracy \\
& Well-oiled machine & (Latin) \\
& (Germanic) & Centralised decision making \\
& Decentralised decision making & Clitist (power and authority) \\
& Specialist, technical competence & Co-ordination at the top \\
& Organised by function & Pyramid of people \\
& Structural solutions & Input control \\
High & Throughput control & Analytic ability \\
$\downarrow$ & Efficiency & High $\rightarrow$ \\
& & Low
\end{tabular}

Source: Schneider \& Barsoux, 1997, p. 84, on the basis of Hofstede and others.

When a multinational firm, such as Philips, operates in the United States, it is accepted almost as a U.S. firm since it is loosely related to the individualistic U.S. society where interaction is explicit, low context, and monochronic. On the other hand, to be successful in Japan, Philips should behave as a Japanese firm, where national culture and corporate culture overlap in a tight, collectivistic society where interaction is implicit, high context, and polychronic. High context cultures use informal implicit ways of communication, while low context cultures need to state messages explicitly in written text. This has implications for the cultural and communication behavior of Western multinationals that wish to be successful in Asian societies. Northwest Europe, which is the home region of Philips, and Latin Europe and America are stages between, with the former having a small overlap between corporate culture and national culture and the latter two regions having corporate culture as part of the national culture. A recent study by Ulijn and Nagel (2000) confirms the different national culture embedding of German and Dutch firms. The Germanic well-oiled machine corporate culture seems to have more prob- 
lems in changing the technology-push culture of young engineers into a market-pull direction than does the Dutch Anglo-Nordic village market corporate culture. Another study (Ulijn \& Weggeman, in press) researched the process of getting young Indonesian engineers involved in the innovation process of the information technology products of a Dutch firm. Both Dutch and Indonesians seemed to gravitate toward the expected ideal innovation culture as a result of low power distance and middle uncertainty avoidance. Other dimensions beyond uncertainty avoidance and power distance, such as loose/tight (Triandis, 1995), individualistic/collectivistic (Hofstede, 1980), and implicit and explicit (Hall \& Hall, 1987,1990 ), might affect the innovative capacity of a firm as well, depending on the national culture.

One typical Asian communication pattern within a firm which fits into the high context/implicit/polychronic/circular pattern is the Japanese Ringi system (Yang, 1984). In this system a document is circulated among managers to gather their sealed agreement. The decision making style is participatory, consensus seeking, and bottom up, but authority is centralized and seniority is respected in a top-down way. As a result, the strategy formulation process in a firm takes much longer than in a Western firm, but once a decision is made, the implementation period is much shorter than in the West.

What impact do communication technologies (especially multimedia, the Internet, and the World Wide Web) have on the interaction among national, corporate, and professional cultures? Do national cultures that prefer an implicit communication style easily accept communiqués over the Internet? Some recent studies (Ulijn \& Campbell, 1999; Ulijn, Lincke, \& Karakaya, in preparation) suggest that this question is still unanswered. If Japanese culture, for instance, silence over speaking and writing because it communicates so well, how would Japanese then deal with the explicit individual means of expression so common with the Internet? Nishigushi (1997) surprisingly demonstrates that at least three distinctive features of Japanese culture explain an Internet boom in Japan. First, the Internet is used as a vehicle for communitarianism. Second, high context allows one to think first before writing or reading, writing being between the silver speaking and the golden silence, an excellent cultural compromise with the non-Japanese world. Finally, home page creation makes the passive, conflict-avoiding Japanese active in expressing themselves. However, are important strategic documents taken seriously if they are the result of open, explicit consultation involving all employees of a firm?

Other research implications involving the confluence of national and corporate cultures include the following. Can the strength of a corporate culture be measured and compared to the effects of national culture? To what extent does the percentage of indigenous versus expatriate members of the workforce within the organization affect the congruence between 
corporate and national culture? The clash of corporate cultures of organizations from different national cultures is well documented (e.g., Daimler-Chrysler). What research can communication scholars offer to help move a culturally merged organization toward shared goals? As multinational firms become more technologically affluent and therefore "virtual," how will these realities influence the sending and receiving of messages in light of the effects of national culture?

\section{Professional Cultures}

A separate issue is determining how the professional cultures of organizational members affect communication and how professional culture is related to the national culture/corporate culture interaction. How does technical innovation take place within a firm? Obviously an innovation has to be offered from one professional culture to others within an organization. The question then is to what extent the successful innovation is technologically pushed or market pulled. Two important audiences are the R\&D department (scientists) and the marketing department. What are their respective professional cultures?

It is a common observation that an emphasis on innovation might precipitate function myopia within a firm. What Marketing wanted, what R\&D proposed, what Finance budgeted for, what Design built, what Production manufactured, and what costumers wanted have often led to completely different concepts of a product. It comes, therefore, as no surprise that innovation projects cause conflicts among departments. Biemans (1993) lists common mutual misperceptions of engineers and marketers. The latter believe that scientists/engineers have no sense of time, costs, service, or competitive advantage. They hide in the lab and continue developing a product without strategic planning, holding standardization and technology sacrosanct, and expecting the client to adapt. The marketers are, in the eyes of the scientists/engineers, aggressive, demanding, and unrealistic. They want everything NOW, want to deliver a product before it is ready, are always in a hurry and impatient, or cannot decide what they want. As a result, they promise more than they can guarantee, often change the specifications because they have no sense of technology, have no trust in scientists/engineers, and are not interested in their problems. Finally, scientists/engineers think that marketers focus on unrealistic targets. Martin (1992) proposes different approaches in addressing the disparate functions of engineering, marketing, and production: integration, differentiation, and fragmentation. An integration approach stresses what employees have in common; differentiation emphasizes the deviations and adaptations from the dominant culture; and fragmentation accepts the dynamic, paradoxical, and confusing character of an intercultural process that is seemingly uncontrollable. Gerhard, 
Amelingmeyer, and Specht (1998) present some instruments used in German firms to manage such interfunctional conflicts.

Allen's (1993) work shows that scientists and engineers need each other in the R\&D department of a technology-intensive company (TIC). Whereas technological innovations will fail without the knowledge provided by the scientists, few scientific insights will lead to innovation unless the engineers intervene. Innovations occur most quickly if the engineer "pulls" the scientist.

Therefore, communication can serve as a cross-pollinator in the innovation process between scientists and engineers in a technology-intensive multinational firm. To what extent can business communication research play a role in this environment? If science leads to the fastest technical innovation when triggered by engineers (technology pulls science), communication may play a role in this process by formulating and implementing informal procedures in the strategic communication of an multinational firm. While scientists have the production of text as their main target (to be cited or perish) and therefore depend heavily on the written word, engineers prefer to design and make concrete products and therefore prefer oral communication with the lay world of clients and suppliers (Allen, 1993). Multinational firms may need to pay more attention to the role of oral communication in strategic innovation and to use international business communicators as bridge builders between different professional cultures.

One of the characteristics of a TIC is the fact that the shop floor is crowded by professional knowledge workers, most of whom are engineers. They are highly skilled employees, performing complicated tasks with individual autonomy. The environment is complex but rather stable, enabling standardization of skills as a coordinating mechanism. Mintzberg (1979) calls this type of organization a professional bureaucracy. Examples are software development companies, firms delivering engineering and technical services, machine tool construction firms, and the like. In the case of a complex and dynamic environment, the coordinating mechanism tends to be mutual adjustment, and the organization is characterized by Mintzberg as an adhocracy. In this category we find industrial research departments, firms engaged in one-of-a-kind technology application projects, and most scientific institutions and technical laboratories (space, air, water, ground). Mintzberg further states that in a professional bureaucracy as well as in an adhocracy, the operating core exerts the dominant influence in contrast to top-management, line-management, and supportstaff departments. Professionals realize that the most expensive and discriminating production factor in TICs is their scarce knowledge, whereas management and supportive capacities are available on a larger scale and, therefore, can be replaced more easily. This dominant influence of the knowledge workers in the operating core on day-to-day organizational life 
gives rise to two related questions: (a) In a professional bureaucracy or adhocracy, does the professional culture of the knowledge workers in the operating core have a greater impact on daily organizational life than does the corporate culture? (b) Is the corporate culture of a professional bureaucracy or adhocracy determined more by the professional culture than by any other organizational subculture?

Based on previous work, we suggest that a collective orientation towards corporate goals is difficult to realize because of the knowledge workers' need for their professional autonomy. Some generic characteristics of professional can be offered, however (Weggeman, 1989):

- Management rules and procedures to operationalize organizational control have only limited influence (professionals do not believe in standard planning and control mechanisms because of the uniqueness and unpredictability of each project).

- Coordination is realized by mutual adjustment achieved through many informal arrangements and get-together routines.

- The reference framework for the assessment of professional contributions lies outside the organization (with peers and professional societies).

- Allocation of assignments is or should be based on individual learning needs and personal preferences.

- There is a common tendency to form subcultures crystallized around "schools of thought" whose specialized jargon is an additional entry barrier.

- In multidisciplinary cooperation, professionals tend to value their own specialization more highly than that of others. Those who admire the practice or skills of other professional groups often critique their underlying theories or methodologies.

- Honesty, openness, consistency, and historical awareness are considered as essential values. There is little sensitivity to political game-playing, outward presentation, and personal appearance as well as little awareness of financial parameters.

- The professional climate stimulates the inclination to exceed requirements and specifications; the result can always be improved and made more beautiful.

In sum, little respect is reserved for managers functioning above the level of first-line supervisor:

The scientist/engineer sees the manager as a bureaucrat, paper shuffler and parasite, an uncreative and unoriginal hack who serves as an obstacle in the way of creative people trying to do a good job-a person more interested in dollars and power than knowledge and innovation (Badawy, 1982, p. 47).

Professional autonomy within organizations is likely to increase in the future. As a consequence of rapid developments in communication tech- 
nologies, the Global Village, predicted by McLuhan in 1964, has been realized. These changes combined with the increase in international trade treaties have raised the mobility of professionals to all-time high. They flow through cross-national networks consisting of high-tech industries, universities, and R\&D institutions (Castells, 1998). As Guéhenno argues in "La Fin de la Démocratie" (1993), the dismantling of the Berlin Wall ended the era in which the national state and the democracy had a major impact. In his view, global networks will be dominant in the near future, networks in which services, information, knowledge, and creative ideas are exchanged and in which contacts and relations are built up and phased out. Multinational companies will take the lead in this process through their professionals and their cultures. It could very well be that national politics become unimportant, territory conflicts will seem trivial, and common public interest will increase. These developments may justify the following proposition: In today's Global Village the professional culture has a higher impact on daily organizational life than does national or corporate culture.

\section{Additional Directions for Research}

In this section, we will offer additional ideas about how communication research might proceed based on the rapidly changing cultural and global environments discussed previously.

\section{How to Study Culture}

It may be an oversimplification to insist that national cultures across the globe are trading values and therefore are converging and becoming more homogenous. Some cultures are more resistant to cultural invasion and integration than others. Still others, upon discerning an unhealthy level of cultural contamination, react with cultural backlash and attempt to eliminate such influences. Examples from Southeast Asia and the Middle East are well known. We should not assume on face value that cultural convergence is rapidly creating its own place in the status quo. Systematic research efforts offer a way to learn more about the existence of this phenomenon and to discover which value systems are more susceptible to cultural convergence. Conversely, considerable evidence (both anecdotal and scientific) provides us with grounds for speculating that global economics and media are substantially influencing intercultural sensitivity. Regardless of whether such influence leads to widespread cultural convergence is a question for research, but we can safely surmise that exposure to new cultural values will create different cognitive and emotional experiences for both insiders and outsiders of a particular culture. The extent to which these experiences affect communication behavior requires study. 
A separate issue concerns the study of communication in organizations that are becoming increasingly global (Parker, 1996). As global organizations become structurally flatter, more interactive, increasingly knowledge-based, geographically scattered, and more culturally diverse, traditional methods of communication analysis will miss the mark. How can the study of business communication be approached in ways that adequately capture the multiplicity of relationships within constantly evolving organizational forms? Will corporate or organizational culture cease to exist as a conceptualizing framework? Will structural evolution require different forms of management and leadership? If so, what are the appropriate means of communicating managerial and leadership strategies? Parker may be correct in suggesting that the time has come to reconsider the "organization" as our unit of analysis. If organizations remain a focus of study for business communication scholars, how do we include in our frameworks the effects of organizational mission and strategy on innovation messages? If organizations construct and adhere to strong institutional missions, their ability to innovate and change during decline will be highly restricted (Mone, McKinley, \& Barker, 1998). Alternatively, firms with flexible missions will be able to adapt to shifting economic or market conditions through innovative practices made possible by less rigidity. Message analysis within both types of organizations would reveal differences in how professionals adapt and mobilize for innovation.

The review presented in an earlier section suggests a closer examination of professional culture as a means for understanding communication in organizations that are global in nature and in those that emphasize innovation. Lovitt (1999) argues quite adamantly that the emphasis on national culture has distracted scholars from investigating a more appropriate culture-that of professional discourse communities. If organizational members identify more with their professional cultures, how should business communication researchers approach the study of messages? Are new theories required for understanding various professional cultures, or can existing theories be adapted? Can theoretical frameworks be developed that capture the complex influence of national, corporate, and professional culture on communication practices? What about individuals? Will our quest for the ultimate "cultural analysis" disregard attitudinal and personality dispositions that we know influence communication behavior, or do we simply allow error variance to account for personal idiosyncrasies?

\section{Approaching Research from New Theoretical Paradigms}

Noted scholars have voiced the need for new approaches to the study of globalism, organizations, and communication (Lewis \& Grimes, 1999; Monge, 1998; Weick, 1999). Weick, in particular, suggests that theory building could move forward when scholars focus a "reflexive" eye on theoretical development. Maintaining a dialogue among scholars and between 
scholars and practitioners provides many opportunities to generate and adapt theories in a rapidly changing environment. It serves no one's interest to cling desperately to theories which offer limited relevance or explanatory power. On the other hand, it is unproductive to ignore theoretical perspectives that have been questioned or poorly tested, or because they do not suit one's worldview. One approach to this tension is employing multiparadigmatic approaches to issues of interest (Lewis \& Grimes, 1999). In essence, multiparadigmatic approaches facilitate the work of scholars who find both value and disappointment in various theoretical perspectives but who understand the need to acknowledge and integrate multiple approaches in an effort to clarify complex and obscure human and organizational phenomena. By applying multiple and divergent perspectives to the study of business communication in cultural contexts, we may be able to explicate issues that were previously neglected because of unilateral or singular theoretical approaches. Employing a multiparadigmatic approach will likely impose additional complexity on the interpretation process, but the recompense is a richer set of explanations and implications that will pay larger theoretical dividends.

Relatedly, given the shifting nature of the context in which business message analysis is most productively situated, theoretical insights may be more generously delivered through a process of multilevel theorizing. Similar to multiparadigmatic approaches, multilevel theories create a more inclusive environment for research. According to Klein, Tosi, and Cannella (1999),

Multilevel theories span the levels of organizational behavior and performance typically describing some combination of individuals, dyads, teams, businesses, corporations, and industries. Multilevel theories, thus, begin to bridge the micro-macro divide, integrating the micro domain's focus on individuals and groups with the macro domain's focus on organizations, environment, and strategy. The result is a deeper, richer portrait of organizational life-one that acknowledges the influence of the organizational context on individuals' actions and perceptions and the influence of individuals' actions and perceptions on the organizational context. (p. 243)

Multilevel theorizing may be especially applicable for research that desires to investigate types of innovation messages among communicators in multinational firms where the influence of national, corporate, and professional cultures is uncertain. It may also offer utility in studies where the organization is experiencing structural or functional change such as in mergers, acquisitions, strategic alliances, or mission or strategy alteration.

\section{REFERENCES}

Albrecht, T. L., \& Hall, B. J. (1991a). Achieving communication goals in superiorsubordinate relationships: The multi-functionality of upward maintenance tactics. Communication Monographs, 58, 273-288. 
Albrecht, T. L., \& Hall, B. J. (1991b). Relational and content differences between elites and outsiders in innovation networks. Human Communication Research, $17,535-561$.

Albrecht, T. L., \& Ropp, U. A. (1984). Communicating about innovation in networks of three U.S. organizations. Journal of Communication, 34, 78-91.

Allen, T. J. (1993). Managing technical communications and technology transfer: Distinguishing science from technology. In T. Allen (Ed.), Managing the flow of technology. London: MIT Press.

Bach, B. W. (1989). The effect of multiplex relationships upon innovation adoption: A reconsideration of Rogers' model. Communication Monographs, 56, 133-150.

Badawy, M. K. (1982). Developing managerial skills in engineers and scientists. New York: Van Nostrand Reinhold.

Barkema, H. J., Bell, J., \& Pennings, J. (1996). Foreign entry, cultural barriers, and learning. Strategic Management Journal, 17, 151-166.

Beamer, L. (1992). Learning intercultural communication competence. The Journal of Business Communication, 29, 285-303.

Bernhardt, S. A. (1999). Using technology to support global drug-development teams. In C. R. Lovitt \& D. Goswami (Eds.), Exploring the rhetoric of inter national professional communication: An agenda for teachers and researchers (pp. 55-80). New York: Baywood.

Biemans, W. G. (1993). Relaties en samnewerking zijn essentieel voor succes bij productontwikkeling, IM Business Marketeer blad.

Bolten, J. (1999). Intercultural business communication: an interactive approach. In C. R. Lovitt \& D. Goswami (Eds.), Exploring the rhetoric of international professional communication: An agenda for teachers and researchers (pp. 139156). New York: Baywood.

Bosley, D. S. (1999). Visual elements in cross-cultural technical communication: Recognition and comprehension as a function of cultural conventions. In C. R. Lovitt \& D. Goswami (Eds.), Exploring the rhetoric of international professional communication: An agenda for teachers and researchers (pp. 253-276). New York: Baywood.

Bourgeois, L. J., \& Brodwin, D. R. (1984). Strategic implementation: Five approaches to an elusive phenomenon. Strategic Management Journal, 5, 241-264.

Branscom, L. M., Florida, R., Hart, D., Keller, J., \& Boville, D. (1999). Investing in innovation. Cambridge, MA: MIT Press.

Castells, M. (1998). End of the millenium: Economy, society, and culture. Oxford: Blackwell.

Cooley, R. C., \& Roach, D. A. (1984). Theoretical approaches to communication competence: A conceptual framework. In R. N. Bostrom (Ed.), Competence in communication (pp. 11-32). Beverly Hills, CA: Sage.

Dougherty, D. (1996). Organizing for innovation. In S. Clegg, C. Hardy, \& W. Nord (Eds.), Handbook of organization studies (pp. 424-439). London: Sage.

Gerhard, B., Amelingmeyer, J., \& Specht, G. (1998). Managing conflicts between the functional units in innovation projects. Paper presented to the 5th International Product Development Conference, Como, Italy.

Gessner, M. J., \& Arnold, V. (1999). Introduction to conceptual perspectives. Advances in Global Leadership, 1, 3-8.

Gessner, M. J., Arnold, V., \& Mobley, W. (1999). Introduction. Advances in Global Leadership, 1, xiii-xviii. 
Guéhenno, J. M. (1995). La fin de la démocratie. Paris: Flammarion.

Gundling, E. (1999). How to communicate globally. Training and Development, 53, 28-32.

Hall, E. T., \& Hall, M. R. (1987). Hidden differences: Doing business with the Japanese. New York: Doubleday.

Hall, E. T., \& Hall, M. R. (1990). Understanding cultural differences: Germans, French, and Americans. Yarmouth, ME: Intercultural Press.

Heerkens, H., \& Ulijn, J. M. (1999). The death of an innovative firm Fokker: Were there cultural reasons? Journal of enterprising culture, $\pi 3$ ), 269-298.

Hilton, C. B. (1992). Japanese international business communication: The place of English. The Journal of Business Communication, 29, 253-265.

Hofstede, G. (1980). Culture's consequences: International differences in workrelated values. Beverly Hills: Sage.

Hofstede, G. (1991). Cultures and organizations: The software of the mind. New York: McGraw Hill.

Hogg, B. A. (1993). European managerial competences. European Business Review, $93,21-26$.

Kalthoff, O., Nonaka, I. \& Nueño, P. (1997). The light and the shadow: How breakthrough innovation is shaping European business. Oxford Center for Innovation/Roland Berger Foundation: Capstone Publishing Limited.

Kaplan, R. (1966). Cultural thought patterns in intercultural education. Language Learning, 16, 1-20.

Klein, K. J., Tosi, H., \& Cannella Jr., A. A. (1999). Multilevel theory building: Benefits, barriers, and new developments. Academy of Management Review, 24, 243-248.

Krone, K. J., Chen, L., \& Xia, H. (1997). Approaches to managerial influence in the People's Republic of China. The Journal of Business Communication, 34, 289-315.

Kumar, R., Ulijn, J., \& Weggeman, M. (1997). Sense making in a globalizing world: The impact of culture on a European multinational firm's strategic behavior. In P. Crubézy, A. Cresson, \& K. Dameron (Eds.), Images, signs, symbols: The cultural coding of communication (pp. 407-415). Poitiers, France: SIETAR.

Lee, J., \& Jablin, F. M. (1992). A cross-cultural investigation of exit, voice, loyalty, and neglect as responses to dissatisfying job conditions. The Journal of Business Communication, 29, 203-228.

Lewis, M. W., \& Grimes, A. J. (1999). Metatriangulation: Building theory from multiple paradigms. Academy of Management Review, 24, 672-690.

Lewis, L., \& Seibold, D. R. (1998). Reconceptualizing organizational change implementation as a communication problem: A review of literature and research agenda. In M. Roloff (Ed.), Communication Yearbook (pp. 93-151). Beverly Hills: Sage.

Little, Arthur D. (1997). Global innovation survey, Cambridge, MA:

Lovitt, C. R. (1999). Introduction: Rethinking the role of culture in international professional communication. In C. R. Lovitt \& D. Goswami (Eds.), Exploring the rhetoric of international professional communication: An agenda for teachers and researchers (pp. 1-16). New York: Baywood.

Martin, J. (1992). Culture in organizations: Three perspectives. Oxford: Oxford University Press. 
Miller, K. I., \& Monge, P. R. (1985). Social information and employee anxiety about organizational change. Human Communication Research, 11, 365-386.

Miller, S. J., Hickson, D. J., \& Wilson, D. C. (1996). Decision-making in organizations. In S. Clegg, C. Hardy, \& W. Nord (Eds.), Handbook of organization studies (pp. 293-312). London: Sage.

Mintzberg, H. (1979). The structuring of organizations: $A$ synthesis of the research. Englewood Cliffs, NJ: Prentice Hall.

Mone, M. A., McKinley, W., \& Barker, V. L. (1998). Organizational decline and innovation: A contingency framework. Academy of Management Review, 23, 115-132.

Monge, P. (1998). Communication structures and processes in globalization. Journal of Communication, 48, 142-153.

Monge, P., \& Fulk, J. (1999). Communication technology for global network organizations. In G. DeSanctis \& J. Fulk (Eds.), Shaping organization form: Communication, connection, and community (pp. 71-100). Thousand Oaks, CA: Sage.

Monge, P. R., \& Eisenberg, E. M. (1987). Emergent communication networks. In F. Jablin, L. Putnam, K. Roberts, \& L. Porter (Eds.), Handbook of organizational communication (pp. 304-342). Newbury Park: Sage.

Morley, D. D., Shockley-Zalabak, P., \& Cesaria, R. (1997). Organizational communication and culture: A study of 10 Italian high-technology companies. The Journal of Business Communication, 34, 252-266.

Nishiguchi, M. (1997), The impact of the INTERNET and the advanced networks on Japanese culture. In P. Crubezy, A. Cresson, \& K. Dameron (Eds.), Images, signs, symbols: The cultural coding of communication (pp. 399-406). Poitiers, France: SIETAR.

Nonaka, I., \& Takeuchi, H. (1995). The knowledge-creating company. New York: Oxford University Press.

Nutt. P. C. (1986). Tactics of implementation. Academy of Management Journal, 29, 230-261.

Nutt. P. C. (1987). Identifying and appraising how managers install strategy. Strategic Management Journal, 8, 1-14.

Nutt. P. C. (1989). Selecting tactics to implement strategic plans. Strategic Management Journal, 10, 145-161.

O'Hair, D., Friedrich, G., Wiemann, J., \& Wiemann, M. (1997). Competent communication. New York: St. Martin's Press.

Ohmae, K. (1998). Strategy in a world without borders. Leader to Leader, 7, 17-23.

O'Neil, H. M., Pouder, R. W., \& Buchhiktz, A. K. (1998). Patterns in the diffusion of strategies across organizations: Insights from the innovation diffusion literature. Academy of Management Review, 23, 98-114.

Park, M. Y., Dillon, W. T., \& Mitchell, K. L., (1998). Korean business letters: Strategies for effective complaints in cross-cultural communication. The Journal of Business Communication, 35, 328-345.

Parker, B. (1996). Evolution and revolution: From international business to globalization. In S. Clegg, C. Hardy, \& W. Nord (Eds.), Handbook of organization studies (pp. 484-506). London: Sage.

Roberts, S. (1991). Technology transfer: An opportunity for technical communicators. Technical Communication, 38, 336-344.

Rogers, E. M. (1983). Diffusion of innovations (3rd Ed.). New York: The Free Press. 
Rogers, E. M. (1996). Diffusion of innovations (4th Ed.). New York: Simon \& Schuster.

Rogers, E. M., \& Shoemaker, F. F. (1971). Communication of innovations: A crosscultural approach (2nd Ed.). New York: The Free Press.

Schneider, S. C., \& Barsoux, J. L. (1997). Managing across cultures. London: Prentice Hall.

Senge, P. M. (1998). The practice of innovation. Leader to Leader, 9, 16-22.

Smeltzer, L. R. (1991). An analysis of strategies for announcing organization-wide change. Group and Organizational Studies, 16, 5-24.

Sriussadaporn-Charoenngam, N., \& Jablin, F. M. (1999). An exploratory study of communication competence in Thai organizations. The Journal of Business Communication, 36, 382-418.

Stage, C. W. (1999). Negotiating organizational communication cultures in American subsidiaries doing business in Thailand. Management Communication Quarterly, 13, 245-280.

Steier, F. (1999). A relational framework for professional communication in international organizations. In C. R. Lovitt \& D. Goswami (Eds.), Exploring the rhetoric of international professional communication: An agenda for teachers and researchers (pp. 157-170). New York: Baywood.

Triandis, H. C. (1995). Culture and social behavior. New York: McGraw Hill.

Ulijn, J. M. (1995). The Anglo-Germanic and Latin concept of politeness and time in cross-Atlantic business communication: From cultural misunderstanding to management success. Intercultural negotiation [Special issue]. Hermes, 15, 1-28.

Ulijn, J. M. (1996). Translating the culture of technical documents: Some experimental evidence. In D. Andrews (Ed.), International Dimensions of Technical Communication (pp. 69-86). Washington: STC.

Ulijn, J. M., \& Campbell, C. P. (1997). International paragraphing: What can cultures learn from each other in the communicative and managerial field? In $\mathbf{M}$. Pütz, B. Smieja, \& M. Tasch (Eds.), Human contact through language and linguistics (pp. 491-500). Frankfurt: Lang Verlag.

Ulijn, J. M., \& Campbell, C. P. (1999). Technical innovations in communication: How to relate technology to business by a culturally reliable human interface. IPCC 99 Proceedings (pp. xx-xx). Piscataway, NJ: IEEE.

Ulijn, J. M., \& Gobits, R. (1986). The role of communication for disseminating scientific and technical innovation. In T. Bungarten (Ed.), Wissenschaftssprache und gesellschaft (pp. 214-232). Hamburg: Akademion.

Ulijn, J. M., Lincke, A., \& Karakaya, Y. (in preparation), Electronics-based international business negotiation vs. face-to face: Some cultural and linguistic aspects. Technical innovation and global business communication [Special issue]. IEEE Transactions on Professional Communication.

Ulijn, J. M., Nagel, A. P. (2000), The cultural transition of the innovation engineer in Germany and NL: From Technology Push to Market Pull. Technical innovation culture in the East and the West [Special issue]. Journal of Enterprising Culture (pp. xx-xx).

Ulijn, J. M., \& St. Amant, K. (2000). Mutual intercultural perception: How does it affect technical communication, some data from China, The Netherlands, Germany, France and Italy. Technical Communication, 47(2), 220-237.

Ulijn, J. M., \& Strother, J.B. (1995). Communicating in business and technology: 
From psycholinguistic theory to international practice. New York/Frankfurt: Lang.

Ulijn, J. M., \& Weggeman, M. (in press). Towards an innovation culture: What are its national, corporate, marketing, and engineering aspects, some experimental evidence? In C. Cooper, S. Cartwright, \& C. Early (Eds.), Handbook of Organisational Culture and Climate. London: Wiley.

Weggeman, M. (1989). Is the professional self-managing or is there really a need for professional management? European Management Journal, 7(4), 422-430.

Weggeman, M., \& Berends, H. (1997). Facilitating knowledge sharing in nonhierarchical work relations. In J. Schreinemakers \& J.-P. Barthès (Eds.), Advances in knowledge management: Vol. 2 (pp. 57-69). Würzburg: Ergon.

Weick, K. E. (1999). Conclusion: Theory construction as disciplined reflexivity: Tradeoffs in the 90s. Academy of Management Review, 24, 797-806.

Weiss, T. (1999). The implications of translation for professional communication. In C. R. Lovitt \& D. Goswami (Eds.), Exploring the rhetoric of international professional communication: An agenda for teachers and researchers (pp. 277292). New York: Baywood.

Yang, C. (1984). Demystifying Japanese management practices. Harvard Business Review, 62(3), 172-178. 